\title{
CUSTOMER ORIENTATION OF B2B FIRMS IN EMERGING MARKETS: EVIDENCE FROM RUSSIA
}

\author{
O. V. GULAKOVA, V.A. REBIAZINA, \\ Faculty of Business and Management, \\ National Research University Higher School of Economics, Russia ${ }^{a}$ \\ M.M.SMIRNOVA \\ Graduate School of Management, Saint Petersburg University, Russia ${ }^{\mathrm{b}}$
}

\begin{abstract}
While the field of customer orientation (CO) has been studied extensively since the 1990s, there have hardly been any attempts to revisit the concept for the specifics of B2B markets, especially in the context of emerging economies. This paper explores the peculiarities of B2B firms' CO on the example of Russia. The empirical survey of 272 Russian B2B firms show that well-established $\mathrm{CO}$ measurement can be used as integrated complex measure. The results of our analysis demonstrate a critically important aspect of $\mathrm{CO}$, which helps to differentiate the customer-oriented firms from those with only "declared" $\mathrm{CO}$. The study indicates a need to critically assess widely used marketing concepts and their measurement in B2B markets of emerging economies.
\end{abstract}

Keywords: customer orientation, B2B, emerging markets, Russia.

JEL: M31.

\section{Introduction}

While the economic effect of customer orientation (CO) implementation has been studied by researchers since the 1990s [Narver, Slater, 1990; Ruekert, 1992; Deshpandé, Farley, Webster, 1993; Ellis, 2006; Jacob, 2006], the nature of client-oriented firms is still a source of ongoing discussion. As a result, there are various perspectives on CO conceptualization: as a decision making [Shapiro, 1988], as a market business logic [Kohli, Jaworski, 1990], as a corporate culture [Narver, Slater, 1990], and as a strategic marketing focus [Ruekert, 1992].

\footnotetext{
a Postal Address: Higher School of Economics, Faculty of Business and Management, 20, Myasnitskaya ul., Moscow, 101000, Russia.

b Postal Address: St. Petersburg State University, Graduate School of Management, 3, Volkhovskiy per., St. Petersburg, 199004, Russia.

(C) O.V.Gulakova, V.A. Rebiazina, M. M.Smirnova, 2019

https://doi.org/10.21638/spbu18.2019.104
} 
One of the key approaches to CO is its interpretation within the broader concept of market orientation (MO) [Shapiro, 1988; Heins, 2000; Ellis, 2006; Coley, Mentzer, Cooper, 2010; Sheppard, 2011; Roersen, Kraaijenbrink, Groen, 2013; Rozhkov, Rebiazina, Smirnova, 2014]. Researches consider CO as one of the MO components [Narver, Slater, 1990], an equal idea [Kohli, Jaworski, 1990] or an independent term [Deshpandé, Farley, Webster, 1993].

However, existing studies, even those focused on B2B firms, do not investigate the peculiarities of $\mathrm{CO}$ in $\mathrm{B} 2 \mathrm{~B}$ as opposed to B2C markets. The studies on B2B samples do not consider the specifics of the B2B context either conceptually or through the lenses of concept operationalization [Siguaw, Simpson, Baker, 1998; Agarwa, Krishna Erramilli, Dev, 2003; Bigné et al., 2004; Kirca, Jayachandran, Bearden, 2005; Hsieh, Chiu, Hsu, 2008; Coley, Mentzer, Cooper, 2010; Roersen, Kraaijenbrink, Groen, 2013; Chakravarty, Kumar, Grewal, 2014; Ziggers, Henseler, 2016; Wang, Zhao, Voss, 2016; Smirnova, Rebiazina, Frösén, 2018; O’Dwyer, Gilmore, 2018].

This study aims to explore the nature of $\mathrm{CO}$ in B2B firms by verifying several existing measurement tools in the B2B context. The specifics of the research context of Russian emerging market provide an additional focus. With very few exceptions, there is insufficient research evidence on how $\mathrm{CO}$ performs and is understood by firms in emerging markets. The few examples are very time dispersed [Greenley, 1995; Golden, Johnson, Smith, 1995; Smirnova et al., 2011; Roersen, Kraaijenbrink, Groen, 2013; Smirnova, Rebiazina, Frösén, 2018]. Russia is a good example of a three decade long transformation from a centrally-planned to a market economy. This transformation still involves substantial changes in managers' perceptions of the core managerial concepts, including $\mathrm{CO}$, as well as the level of customer sophistication and expectations. Moreover, $\mathrm{CO}$ was proclaimed to be a core driving force of the transformation process and one of the most important firms' strategic capabilities that replaced supplier orientation dominating the planned economy [Farley, Deshpandé, 2006].

This study contributes to understanding the specifics of B2B firms' $\mathrm{CO}$ on the example of Russia's emerging economy. First, we critically review the existing literature on specifics of $\mathrm{CO}$ for both $\mathrm{B} 2 \mathrm{~B}$ markets and emerging economies. Then we conduct an empirical research on B2B firms in the Russian market. Our study helps to re-evaluate the specifics of $\mathrm{CO}$ in the context of both B2B markets and emerging economies and provides agenda for further research and potential adaptation of this concept for future studies.

\section{Literature review}

\section{B2B market perspective: Existing research on $\mathrm{CO}$}

While there is a growing interest in $\mathrm{CO}$, the number of publications on this topic in B2B markets is significantly less than in B2C markets. From 1995 to 2008 only about $10 \%$ of the total articles on MO are published in top B2B journals (Appendix 1). However, MO and $\mathrm{CO}$ are in the area of interest of B2B research [Liao et al., 2011; Frösén et al., 2016; Pekovic, Rolland, Gatignon, 2016; O’Dwyer, Gilmore, 2018]. Moreover, many studies use B2B samples but do not adjust methodology or interpret the results through the lenses of the $\mathrm{B} 2 \mathrm{~B}$ context; they apply well-established concepts in order to explain firm behavior in B2B markets, rather than explain the concept. The majority of B2B studies apply the measurement tools developed by [Narver, Slater, 1990; Jaworski, Kohli, 1993]. Depending on the scientific preferences and goals of the research the authors build their hypotheses and models on the general theory of CO [Liao et al., 2011; Iyer et al., 2018; Park et al., 2018].

The overview of existing B2B studies shows that the relationship between MO and firm performance is mostly positive, 
equally for the mixed B2B/B2C samples [Narver, Slater, 1990; Jaworski, Kohli, 1993; Slater, Narver, 1994; Homburg, Pflesser, 2000; Zhou, Brown, Dev, 2009; Smirnova et al., 2011; Wilden, Gudergan, Lings, 2018; Bommaraju et al., 2019]. [Dickson, 1992; Kohli, Jaworski, Kumar, 1993] explain the dilemma that consumer market producers face when implement the MO without the CO component. [Cooley, Mentzer, Cooper, 2010, p. 142] emphasize this concern because "market-oriented producers have both retail customers, who help to facilitate the distribution of their products, and consumers, who buy the producer's products from the producer's customers, as well as competitors in their market space”.
B2B literature on CO predominantly focuses on comparisons between developed and emerging markets [Adhikari, Gill, 2011; Singh, Koshy, 2011] or between manufacturing and service firms [Agarwal, Krishna Erramilli, Dev, 2003; Kirca, Jayachandran, Bearden, 2005; Sin et al., 2005; Tsiotsou, 2010; Wang, Zhao, Voss, 2016], rather than on the differences in $\mathrm{CO}$ of $\mathrm{B} 2 \mathrm{C}$ and $\mathrm{B} 2 \mathrm{~B}$ markets. However, an analysis of the directions of research shows that there are some specifics of investigating $\mathrm{CO}$ and $\mathrm{MO}$ in the B2B market [Coley, Mentzer, Cooper, 2010]. The overview of the existing literature identifies the following main dimensions, which are considered through the lenses of a B2B context in exploring the nature and the role of CO (Table 1).

Table 1

Existing research on B2B CO in emerging markets

\begin{tabular}{|c|c|c|c|c|c|c|c|c|}
\hline \multirow[b]{2}{*}{ Article } & \multirow[b]{2}{*}{$\begin{array}{l}\text { MO/ } \\
\text { CO }\end{array}$} & \multirow[b]{2}{*}{ Country } & \multirow{2}{*}{$\begin{array}{l}\text { Level } \\
\text { of } \\
\text { CO/ } \\
\text { MO }\end{array}$} & \multicolumn{4}{|c|}{ Methodology } & \multirow[b]{2}{*}{$\begin{array}{c}\text { Focus } \\
\text { on B2B } \\
\text { context }\end{array}$} \\
\hline & & & & $\begin{array}{l}\text { Data } \\
\text { collection } \\
\text { method(s) }\end{array}$ & $\begin{array}{c}\text { Source } \\
\text { of the measurement } \\
\text { scale }\end{array}$ & Sample & $\begin{array}{l}\text { Method(s) } \\
\text { of analysis }\end{array}$ & \\
\hline $\mathbf{1}$ & 2 & 3 & 4 & 5 & 6 & 7 & 8 & 9 \\
\hline $\begin{array}{l}\text { [Golden, } \\
\text { Johnson, } \\
\text { Smith, } \\
\text { 1995] }\end{array}$ & MO & Russia & Firm & Survey & $\begin{array}{l}\text { [Snow, Hrebiniak, } \\
\text { 1980] }\end{array}$ & $\begin{array}{l}200 \mathrm{~B} 2 \mathrm{~B} \\
\& \mathrm{~B} 2 \mathrm{C} \\
\text { firms }\end{array}$ & ANOVA & No \\
\hline $\begin{array}{l}\text { Chan } \\
\text { Hung } \\
\text { Ngai, } \\
\text { Ellis, } \\
\text { 1998] }\end{array}$ & MO & China & Firm & Survey & $\begin{array}{l}\text { [Narver, Slater, } \\
\text { 1990] (MKTOR) }\end{array}$ & $\begin{array}{l}73 \mathrm{~B} 2 \mathrm{~B} \& \\
\mathrm{~B} 2 \mathrm{C} \text { firms }\end{array}$ & $\begin{array}{l}\text { Multiple linear } \\
\text { regression }\end{array}$ & No \\
\hline $\begin{array}{l}\text { [Akimo- } \\
\text { va, } \\
2000]\end{array}$ & MO & Ukraine & Firm & $\begin{array}{l}\text { Survey, in- } \\
\text { depth in- } \\
\text { terviews }\end{array}$ & $\begin{array}{l}\text { [Hooley, Lynch, } \\
\text { Shepherd, 1990; } \\
\text { Marinov et al., } \\
\text { 1993] }\end{array}$ & $\begin{array}{l}221 \mathrm{~B} 2 \mathrm{~B} \\
\& \mathrm{~B} 2 \mathrm{C} \\
\text { firms }\end{array}$ & $\begin{array}{l}\text { Cluster analysis, } \\
\text { ANOVA }\end{array}$ & No \\
\hline $\begin{array}{l}\text { [Hajjat, } \\
2002]\end{array}$ & $\mathrm{CO}$ & $\begin{array}{l}\text { Middle } \\
\text { East } \\
\text { country* }\end{array}$ & Firm & $\begin{array}{l}\text { Survey in- } \\
\text { depth in- } \\
\text { terviews }\end{array}$ & $\begin{array}{l}\text { [Hajjat, 2002] } \\
\text { (CUSTOR) }\end{array}$ & $\begin{array}{l}197 \mathrm{~B} 2 \mathrm{~B} \\
\& \mathrm{~B} 2 \mathrm{C} \\
\text { firms }\end{array}$ & CFA & No \\
\hline $\begin{array}{l}\text { Kaynak, } \\
\text { Kara, } \\
2004] \\
\end{array}$ & MO & China & Firm & Survey & $\begin{array}{l}\text { [Kohli, Jarworski, } \\
\text { Kumar, 1993] } \\
\text { (MARKOR) }\end{array}$ & $\begin{array}{l}179 \mathrm{~B} 2 \mathrm{~B} \\
\& \mathrm{~B} 2 \mathrm{C} \\
\text { firms }\end{array}$ & $\begin{array}{l}\text { EFA, CFA, clus- } \\
\text { ter analysis, cor- } \\
\text { relation analysis }\end{array}$ & Yes \\
\hline $\begin{array}{l}\text { Farley, } \\
\text { Desh- } \\
\text { pandé, } \\
\text { 2006] }\end{array}$ & MO & Russia & Firm & Survey & $\begin{array}{l}\text { [Deshpandé, Farley, } \\
\text { Webster, 1993; } \\
\text { Deshpandé, Farley, } \\
\text { 1998] }\end{array}$ & $\begin{array}{l}158 \mathrm{~B} 2 \mathrm{~B} \\
\text { firms }\end{array}$ & ANOVA & Yes \\
\hline
\end{tabular}


Table 1 (continued)

\begin{tabular}{|c|c|c|c|c|c|c|c|c|}
\hline 1 & 2 & 3 & 4 & 5 & 6 & 7 & 8 & 9 \\
\hline $\begin{array}{l}\text { [Ozer, } \\
\text { Koçak, } \\
\text { Çelik, } \\
2006]\end{array}$ & MO & Turkey & Firm & Survey & $\begin{array}{l}\text { [Kohli, Jarworski, } \\
\text { Kumar, 1993; } \\
\text { Jaworski, Kohli, } \\
\text { 1993; Narver, } \\
\text { Slater, 1990; } \\
\text { Desphandé, Farley, } \\
\text { 1998; Gray, Hooley, } \\
\text { 2002] }\end{array}$ & $\begin{array}{l}1042 \text { B2B } \\
\text { firms }\end{array}$ & EFA, CFA & Yes \\
\hline $\begin{array}{l}\text { [Chung } \\
\text { et al., } \\
2011]\end{array}$ & MO & China & $\begin{array}{l}\text { Inter- } \\
\text { firm } \\
\text { dyad }\end{array}$ & Survey & $\begin{array}{l}\text { [Matsuno, Mentzer, } \\
\text { Rentz, 2000] }\end{array}$ & $\begin{array}{l}99 \text { B2B } \\
\text { dyads (re- } \\
\text { tailer-sup- } \\
\text { plier) }\end{array}$ & CFA, SEM & Yes \\
\hline $\begin{array}{l}\text { [Smirno- } \\
\text { va et al., } \\
2011]\end{array}$ & MO & Russia & Firm & Survey & $\begin{array}{l}\text { [Narver, Slater, } \\
\text { 1990] (MKTOR) }\end{array}$ & $\begin{array}{l}158 \mathrm{~B} 2 \mathrm{~B} \\
\text { firms }\end{array}$ & CFA, SEM & Yes \\
\hline $\begin{array}{l}\text { [Roer- } \\
\text { sen, } \\
\text { Kraai- } \\
\text { jenbrink, } \\
\text { Groen, } \\
\text { 2013] }\end{array}$ & MO & Russia & Firm & Survey & $\begin{array}{l}\text { [Narver, Slater, } \\
\text { 1990] (MKTOR) }\end{array}$ & $\begin{array}{l}10 \text { B2B \& } \\
\text { B2C firms }\end{array}$ & $\begin{array}{l}\text { Mean values anal- } \\
\text { ysis }\end{array}$ & No \\
\hline $\begin{array}{l}\text { [Sarkar, } \\
\text { Mishra, } \\
\text { 2017] }\end{array}$ & MO & India & $\begin{array}{l}\text { Inter- } \\
\text { firm } \\
\text { dyad }\end{array}$ & $\begin{array}{l}\text { Survey, } \\
\text { interviews }\end{array}$ & $\begin{array}{l}\text { [Kohli, Jarworski, } \\
\text { Kumar, 1993] } \\
\text { (MARKOR) }\end{array}$ & $\begin{array}{l}174 \text { B2B } \\
\text { dyads } \\
\text { (buyer- } \\
\text { seller) }\end{array}$ & EFA, SEM & Yes \\
\hline $\begin{array}{l}\text { This } \\
\text { study }\end{array}$ & $\mathrm{CO}$ & Russia & Firm & $\begin{array}{l}\text { Survey, } \\
\text { in-depth } \\
\text { interviews }\end{array}$ & $\begin{array}{l}\text { [Narver, Slater, } \\
\text { 1990] (MKTOR) } \\
\text { [Narver, Slater, } \\
\text { MacLachlan, 2004; } \\
\text { Deshpandé, Farley, } \\
\text { Wedster, 1993] }\end{array}$ & $\begin{array}{l}272 \mathrm{~B} 2 \mathrm{~B} \\
\text { firms }\end{array}$ & $\begin{array}{l}\text { EFA, cluster } \\
\text { analysis, content } \\
\text { analysis }\end{array}$ & Yes \\
\hline
\end{tabular}

Note: ${ }^{*}$ - the author didn't specify country; ANOVA - analysis of variance, EFA - exploratory factor analysis, CFA - confirmatory factor analysis, SEM - structural equation modeling.

Resulting from our literature review, there are three main directions of research in B2B firms' CO. The first direction tries to identify $\mathrm{CO}$ of an individual salesmen even before the concept has been widely tested at the firm-level [Saxe, Weitz, 1982]. For B2B firms, CO on employee level has substantial importance as there are fewer customers and building strong relationships is vital part of business [Singh, Koshy, 2011; Farias, Torres, Cortez, 2017; Babu, 2018; Herhausen, De Luca, Weibel, 2018; Lussier, Hall, 2018].
The second direction of B2B marketing focuses on value creation [Viardot, 2017] and considers $\mathrm{CO}$ as a platform for customer value creation [O'Cass, Ngo, Siahtiri, 2012]. The role of CO is to positively affect relationship building and consequently value creation. This factor is even more important for current research as value creation in B2B markets is often only possible when customers are ready to co-create value. This highlights the critical role of $\mathrm{CO}$ as a driver of customer involvement and collaboration. 
The third direction of B2B CO research is the relationship management framework [Charterina, Basterretxea, Landeta, 2016; Khan, Zolkiewski, Murphy, 2016; Bommaraju et al., 2019]. From this perspective, CO is a tool for developing relationships with customers. It is suggested that $\mathrm{CO}$ does not directly influence firm performance, it rather positively affect the ability to build relationships with customers, which in turn influence performance [Smirnova et al., 2011; Guo, Wang, 2015].

The emerging markets perspective in $\mathrm{CO}$ research: A focus on the Russian market

The increasing interest in $\mathrm{CO}$ applies not only for firms in developed markets, but also in emerging markets, in particular in BRICS [Smirnova et al., 2011; Kraaijenbrink, Roersen, Groen, 2009; Rozhkov, 2014; Popov, Tretyak, 2014; Rozhkov, Rebiazina, Smirnova, 2014].

Since the beginning of 1990s the Russian economy has undergone several waves of changes that forced firms to revise their approaches to marketing, including $\mathrm{CO}$. The transition of the Russian economy (from centrally planned to open market) made firms transfer from producer- to marketoriented [Farley, Deshpandé, 2006]. The growing number of competitors, including foreign corporations, contributed to the adoption of marketing concepts from developed markets. However, lack of actual studies does not allow us to conclude how firms have adapted such concepts in a process of implementation. Those few studies published earlier demonstrate that the established concepts can be both misinterpreted [e.g. Roersen, Kraaijenbrink, Groen, 2013] or lead to unexpected results in new contexts [Smirnova, Rebiazina, Frösén, 2018].

In the first decade of the 2000s when the Russian economy showed a significant improvement in terms of stability and growth, firms could easily grow by following the market growth. But the newest challenges have been brought to Russian economy by the world economic crisis in 2008-2009, followed by the Russian currency crisis in 2014 and subsequent economic recession. Further growth or even survival during the 2010 s required firms to revisit their strategies, including customer-related.

Existing research however can hardly grasp these developments, since the studies on the Russian market are fragmented and insufficient in comparison to existing studies on developed markets. Despite the obvious lack of a benchmark for Russian firms and little understanding of market-oriented strategies and behaviors, research shows that the significance of marketing increased among all types of Russian firms once the centrally planned economy was abandoned [Golden, Johnson, Smith, 1995; Akimova, 2000; Farley, Deshpandé, 2006]. The results of the study by [Smirnova et al., 2011] confirmed that Russian B2B firms are more competitor-oriented. On the whole, studies identified a low level of CO in Russian firms [Farley, Deshpandé, 2006; Roersen, Kraaijenbrink, Groen, 2013], highlighting need to identify the reasons and factors contributing to it.

The analysis of Russian and developed market literature shows the scholars' interest in $\mathrm{CO}$ but the lack of studies that apply this concept specifically in the B2B context. Despite the peculiar features of the B2B context there is no distinctive theoretical base for B2B studies. Most papers use B2B samples but extend their findings to both $\mathrm{B} 2 \mathrm{~B}$ and B2C markets. Common methods, models, and scales are used both for B2B and $\mathrm{B} 2 \mathrm{C}$ research, but the specifics of $\mathrm{CO}$ in $\mathrm{B} 2 \mathrm{~B}$ markets raise a question about the adequateness of using general scales and the need for their adaptation.

\section{Methodology}

\section{Operationalization}

In investigating the conceptual and operational nature of $\mathrm{CO}$ several measurement tools are usually used: MKTOR scale 
[Narver, Slater, 1990], 9-item scale of [Deshpandé, Farley, Webster, 1993] and proactive and reactive $\mathrm{MO}$ scale [Narver, Slater, MacLachlan, 2004]. Since the concept of $\mathrm{CO}$ is inextricably linked to MO, it was decided to use MKTOR scale as the basis for the questionnaire [Narver, Slater, 1990]. The MKTOR scale is adapted for and used in developed markets context. It evaluates $\mathrm{CO}$ in comparison with other elements of MO: competitor orientation and inter-functional coordination. The adoption procedure included potentially diverse items from existing scales, which might provide insights into the dimensionality and the content of the construct in the B2B context. The resulting scale involved MKTOR scale [Narver, Slater, 1990]; proactive and reactive MO scale and 9-item scale of [Deshpandé, Farley, Webster, 1993]. Our final instrument totaled 24 indicators (Table 2).

\section{Data collection process and sample description}

The empirical data for the study was collected in 2015 in the form of online survey. The questionnaire was sent to the representatives of marketing and sales departments and top management of B2B firms. As a result, 310 responses were collected, 272 of

Table 2

Operationalization of variables for the scale of the quantitative empirical research

\begin{tabular}{|c|c|c|}
\hline Indicator & Indicator label & Scale \\
\hline 1 & 2 & 3 \\
\hline K1 & We are committed to customers & \multirow{6}{*}{$\begin{array}{l}\text { MKTOR [Narver, } \\
\text { Slater, 1990] }\end{array}$} \\
\hline $\mathrm{K} 2$ & We create customer value & \\
\hline K3 & We understand customer needs & \\
\hline K4 & Customer satisfaction is one of our objectives & \\
\hline K5 & We offered after-sales service & \\
\hline K6 & We measure customer satisfaction & \\
\hline K7 & We help our customers anticipate developments in their markets & \multirow{8}{*}{$\begin{array}{l}\text { Proactive market ori- } \\
\text { entation [Narver, } \\
\text { Slater, MacLachlan, } \\
\text { 2004] }\end{array}$} \\
\hline K8 & $\begin{array}{l}\text { We continuously try to discover additional needs of our customers } \\
\text { of which they are unaware }\end{array}$ & \\
\hline K9 & $\begin{array}{l}\text { We incorporate solutions to unarticulated customer needs in our new } \\
\text { products and services }\end{array}$ & \\
\hline K10 & We brainstorm on how customers use our products and services & \\
\hline K11 & We innovate even at the risk of making our own products obsolete & \\
\hline K12 & $\begin{array}{l}\text { We search for opportunities in areas where customers have a difficult } \\
\text { time expressing their needs }\end{array}$ & \\
\hline K13 & $\begin{array}{l}\text { We work closely with lead users who try to recognize customer needs } \\
\text { months or even years before the majority of the market may recognize } \\
\text { them }\end{array}$ & \\
\hline K14 & $\begin{array}{l}\text { We extrapolate key trends to gain insight into what users in a current } \\
\text { market will need in the future }\end{array}$ & \\
\hline K15 & $\begin{array}{l}\text { We constantly monitor our level of commitment and orientation } \\
\text { to serving customer needs }\end{array}$ & \multirow{4}{*}{$\begin{array}{l}\text { Reactive market orien- } \\
\text { taton [Narver, Slater, } \\
\text { MacLachlan, 2004]. } \\
\text { 9-item scale } \\
\text { [Deshpandé, Farley, } \\
\text { Wedster, 1993] }\end{array}$} \\
\hline K16 & $\begin{array}{l}\text { Our strategy for competitive advantage is based on our understanding } \\
\text { of customers' needs }\end{array}$ & \\
\hline K17 & We are more customer focused than our competitors & \\
\hline K18 & I believe this business exist primarily to serve customers & \\
\hline
\end{tabular}


Table 2 (continued)

\begin{tabular}{c|l|l}
\hline $\mathbf{1}$ & \multicolumn{1}{|c|}{$\mathbf{2}$} & \multicolumn{1}{|c}{3} \\
\hline K19 & $\begin{array}{l}\text { Data on customer satisfaction are disseminated at all levels of this } \\
\text { business unit on a regular basis }\end{array}$ & $\begin{array}{l}\text { Reactive market orien- } \\
\text { taton [Narver, Slater, } \\
\text { MacLachlan, 2004] }\end{array}$ \\
\hline K20 & We know our competitors well & $\begin{array}{l}\text { 9-item scale } \\
\text { [Deshpandé, Farley, } \\
\text { Webster, 1993] }\end{array}$ \\
\hline K21 & $\begin{array}{l}\text { We have a good sense of how our customers value our products } \\
\text { and services }\end{array}$ & \\
\cline { 1 - 1 } K22 & We compete primarily based on product or service differentiation \\
\cline { 1 - 1 } K23 & The customer's interest should always come first, ahead of the owners' & \\
\hline K24 & Our products/services are the best in the business & \\
\hline
\end{tabular}

them were appropriate for the further analysis (Appendix 2). After the data collection some representatives were interviewed to clarify the results.

The study was built on the stratified sampling according to two criteria: (a) offering (B2B product or B2B services) and (b) location (federal cities - Moscow and St.Petersburg - and the other Russian regions).

The sample consisted of $46.3 \%$ B2B firms and $53.7 \%$ firms operating on both B2B and B2C markets. $25.4 \%$ of sample firms are product-oriented firms, $45.6 \%$ represent services firms; $29 \%$ produce both goods and services. The respondents belonged to the firms with Russian capital (74.3\%), foreign capital $(11 \%)$ and joint capital (14.7\%).

\section{Empirical results}

\section{Descriptive statistics}

Appendix 3 presents the means, standard deviations, and reliability indicators. The overall scale reliability is high (Cronbach's Alpha $=0.918$ ). Most of the indicators related to $\mathrm{CO}$ have high average means.

The overall conclusion based on the analysis of descriptive statistics is that the sample firms pay little attention to the measurement of customer satisfaction and their commitment to finding out the latent needs of customers. These results confirm the assumption of the declared CO of Russian firms [Popov, Tretyak, 2014]. In the firms' responses there are only external signs of
CO. The respondents noted that their firms have customer satisfaction as objectives, but there is no component of cohesive approach, in other words, there is no evidence of well-established $\mathrm{CO}$ practices in these firms.

\section{Factor analysis results}

To identify the main latent factors that reflect CO we applied exploratory factor analysis (EFA) with varimax rotation for the initial pool of 24 items using SPSS software. Three items (K16, K18, K22) had factor loadings lower than 0.5 and were excluded from further analysis. Three further items (K4, K5, K24) demonstrated substantial cross-loadings and were also eliminated. Table 3 presents the results of EFA for the remaining 18 items $(\alpha=0.898)$, whereas the four-factor solution explains $60.4 \%$ of variance.

The main goal of EFA was to identify a potential structure of the combined scales [Narver, Slater, 1990; Deshpandé, Farley, Webster, 1993; Narver, Slater, 2004]. The results demonstrate that indicator allocation does not fully match the latent factors of the original scales of Narver and Slater [Narver, Slater, 1990, 2004], and Deshpandé, Farley, and Webster [Deshpandé, Farley, Webster, 1993]. Instead, all indicators were divided into 4-factors:

(1)proactive $\mathrm{CO}$ : grouped the items corresponding to the the original scale for proactive CO by [Narver, Slater, MacLachlan, 2004]; 
Table 3

Rotated component matrix (18 items)

\begin{tabular}{|c|c|c|c|c|c|}
\hline \multirow{3}{*}{ 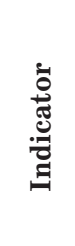 } & \multirow[b]{3}{*}{ Indicator label } & \multicolumn{4}{|c|}{ Factor } \\
\hline & & 1 & 2 & 3 & 4 \\
\hline & & Proactive CO & $\begin{array}{l}\text { Customer } \\
\text { interest and } \\
\text { satisfaction } \\
\text { importance }\end{array}$ & $\begin{array}{l}\text { Value for } \\
\text { customer }\end{array}$ & $\begin{array}{l}\text { Orientation } \\
\text { both for } \\
\text { customers and } \\
\text { competitors }\end{array}$ \\
\hline K11 & $\begin{array}{l}\text { We innovate even at the risk of making } \\
\text { our own products obsolete }\end{array}$ & 0.779 & & & \\
\hline K8 & $\begin{array}{l}\text { We continuously try to discover addi- } \\
\text { tional needs of our customers of which } \\
\text { they are unaware }\end{array}$ & 0.718 & & & \\
\hline K14 & $\begin{array}{l}\text { We extrapolate key trends to gain } \\
\text { insight into what users in the current } \\
\text { market will need in the future }\end{array}$ & 0.710 & & & \\
\hline K12 & $\begin{array}{l}\text { We search for opportunities in areas } \\
\text { where customers have a difficult time } \\
\text { expressing their needs }\end{array}$ & 0.701 & & & \\
\hline K13 & $\begin{array}{l}\text { We work closely with lead users who try } \\
\text { to recognize customer needs months or } \\
\text { even years before the majority of the } \\
\text { market may recognize them }\end{array}$ & 0.666 & & & \\
\hline K9 & $\begin{array}{l}\text { We incorporate solutions to unarticu- } \\
\text { lated customer needs in our new } \\
\text { products and services }\end{array}$ & 0.621 & & & \\
\hline K10 & $\begin{array}{l}\text { We brainstorm on how customers use } \\
\text { our products and services }\end{array}$ & 0.608 & & & \\
\hline K7 & $\begin{array}{l}\text { We help our customers anticipate } \\
\text { developments in their markets }\end{array}$ & 0.538 & & & \\
\hline K19 & $\begin{array}{l}\text { Data on customer satisfaction are } \\
\text { disseminated at all levels of this business } \\
\text { unit on a regular basis }\end{array}$ & & 0.781 & & \\
\hline$\overline{\mathrm{K} 15}$ & $\begin{array}{l}\text { We constantly monitor our level } \\
\text { of commitment and orientation } \\
\text { to serving customer needs }\end{array}$ & & 0.721 & & \\
\hline K6 & We measure customer satisfaction & & 0.673 & & \\
\hline $\mathrm{K} 23$ & $\begin{array}{l}\text { The customer's interest should always } \\
\text { come first, ahead of the owners' }\end{array}$ & & 0.615 & & \\
\hline K17 & $\begin{array}{l}\text { We are more customer focused than our } \\
\text { competitors }\end{array}$ & & 0.526 & 0.403 & \\
\hline $\mathrm{K} 2$ & We create customer value & & & 0.834 & \\
\hline K1 & We are committed to customer & & & 0.823 & \\
\hline K3 & We understand customer & & & 0.580 & \\
\hline $\mathrm{K} 20$ & We know our competitors well & & & & 0.830 \\
\hline K21 & $\begin{array}{l}\text { We have a good sense of how our } \\
\text { customers value our products and } \\
\text { services }\end{array}$ & & 0.443 & & 0.589 \\
\hline
\end{tabular}


Table 4

\section{Clusters description}

\begin{tabular}{c|l|c|l}
\hline $\begin{array}{c}\text { Cluster } \\
\text { No. }\end{array}$ & \multicolumn{1}{|c|}{ Cluster name } & $\begin{array}{c}\text { Number } \\
\text { of respondents }\end{array}$ & \multicolumn{1}{c}{ Main features } \\
\hline I & "Truly customer-oriented” & $83(31 \%)$ & High values of most of all CO indicators \\
\hline II & "Declarers” & $57(21 \%)$ & $\begin{array}{l}\text { Low values of proactive CO indicators; low values } \\
\text { of indicators based on customer satisfaction and } \\
\text { loyalty }\end{array}$ \\
\hline III & "Low customer-oriented” & $31(11 \%)$ & Low values of all CO indicators \\
\hline IV & "Strivers" & $72(26 \%)$ & $\begin{array}{l}\text { Average values on all indicators of Priority } \\
\text { to customer interest factor; average values on } \\
\text { learning about customers and their satisfaction }\end{array}$ \\
\hline V & "CO newcomers" & $29(11 \%)$ & $\begin{array}{l}\text { High values of customer commitment; low values } \\
\text { of indicators related to innovations, customer } \\
\text { monitoring }\end{array}$ \\
\hline
\end{tabular}

(2)customer interest and satisfaction importance: this latent factor grouped the items from the original MKTOR scale [Narver, Slater, 1990], 9-item CO scale by [Deshpandé, Farley, Webster, 1993] and the reactive CO scale by [Narver, Slater, 1990; MacLachlan, 2004];

(3) value for customer: these items, to a large extent, corresponded to the items from the original MKTOR scale [Narver, Slater, 1990];

(4)customer \& competitor orientation: these items correspond to one part of the 9-item CO scale by [Deshpandé, Farley, Webster, 1993].

\section{Cluster analysis results}

Based on the revealed factorial structure of $\mathrm{CO}$ construct an additional cluster analysis was conducted. It resulted in the identification of five clusters with different focuses on CO elements (Table 4).

The cluster analysis was conducted in two stages: at the first stage, a hierarchical clustering was carried out, at the second stage - non-hierarchical clustering. Since it is difficult to determine the exact number of clusters in a given sample, non-hierarchical clustering was performed by K-means method for the number of clusters in the range of three to six. Further analysis indicated that the optimal results could be achieved with five clusters. Table 4 presents the final cluster solution and clusters' characteristics.

The results of the cluster analysis provide a deeper perspective on how Russian B2B firms understand, implement and adjust $\mathrm{CO}$ in practice. $68 \%$ of firms try to implement $\mathrm{CO}$ in a reduced form, whereas diverse angles of the concept are emphasized (clusters I, IV and V). However, a holistic implementation of all $\mathrm{CO}$ dimensions is undertaken only by "truly customer-oriented" firms (cluster I).

Cluster I ("Truly customer-oriented firms", $31 \%$ ) is characterized by the highest levels of all the $\mathrm{CO}$ indicators (4-5 from 5). This is the largest cluster (83 respondents) that also contains most firms with foreign capital, which might explain the high level of CO. Foreign firms have successfully transferred CO philosophy and practices from developed markets to the Russian market. Moreover, the Cluster I firms are geographically located in large federal cities, and their offering includes both B2B and B2C services. The high level of competition in federal cities can explain the importance of $\mathrm{CO}$ for the firms in this cluster. The size of the cluster firms varies with nearly half of the cluster firms representing SMEs with less than 100 employees.

Cluster II ("Declarers", $21 \%$ of sample firms) includes firms with a so-called "declared" CO [Popov, Tretyak, 2014]. A "declared" 
CO implies the firm accepts most important client values and customer interests, however does not demonstrate any supporting consistent behaviour and organizational processes. Hence, the indicators on proactive $\mathrm{CO}$, evaluating customer satisfaction and loyalty in this cluster firms have very low values. Surprisingly, the cluster is mostly represented by the $\mathrm{B} 2 \mathrm{~B}$ services firms. During the in-depth interviews some firms explained $\mathrm{CO}$ through the notion of quality. It represents a rather faulty understanding of $\mathrm{CO}$ concept, which may drive overall offering focus that is not supported by a deeper exploration of customer needs or following up after the service is provided:

"CO is perceived as one of the main components of the high [offering] quality".

Firm A, electronic producer

\section{"...For our firm CO is first of all the speed and quality of our services".}

Firm B, leading travel company

Cluster III ("Low customer-oriented", $11 \%$ ) consists of firms, where CO is very low. These are mostly B2B services firms from federal cities. All elements of $\mathrm{CO}$ assessed by these firms are below the average. These firms are oriented towards existing products and services and aim to protect their market niche. For the same purpose, they monitor the level of customer satisfaction to ensure customer loyalty. There is rather low attention to proactive $\mathrm{CO}$, innovations, product and customer need development.

Cluster IV ("Strivers", 26\%) consists of firms developing a customer-oriented approach and trying to achieve competitiveness through it. Representatives of this cluster currently implement just some aspects of $\mathrm{CO}$, but aim to develop them further for a competitive advantage. They are focused on discovering latent customer needs aiming to increase customer satisfaction and monitoring the CO level. Most of the cluster is represented by the firms based in federal cities, offering mainly services in both B2C and B2B markets.

Finally, cluster V (“CO newcomers", 11\%) includes mostly firms with high customer commitment, but currently lacking a CO. They evaluate their level of $\mathrm{CO}$ as low on the core indicators, but provide high-level scores on indicators of value for the customer (e.g. "the customer's interest should always come first, ahead of the owners"). The main characteristic of this cluster is the domination of pure B2B firms, operating mainly in the B2B services area and located in regions. The regional location of the firms and their limited market experience (less than 5 years) might be an essential factor in their lack of customer focus. Lower competition in the regions might also be a factor that leads to a deviation from the $\mathrm{CO}$ focus in favour of other strategic orientations.

Table 5 provides an overview of the clusters with focus on the main firm characteristics: region, age, capital affiliation, market, market offer and firm size.

\section{Discussion and conclusion}

\section{Theoretical implications}

The study's aim was to explore the nature and specifics of $\mathrm{CO}$ perception and application by B2B firms. Additionally, it focused on the Russian economy as the emerging market context. The firm-level data on a set of well-established CO measures was analysed using a sequential methodological approach. The analysis involved exploring the latent factorial structure through EFA, interpretation of the resulted latent factors and identification of the firms clusters that reflected various degrees of prioritization of the $\mathrm{CO}$ and its subdimensions.

The results of EFA indicated the discrepancies in firms' perception of $\mathrm{CO}$ concept subdimensions, based on preselected three core scales. As an outcome, four distinctive factors were identified, which did not match the pre-selected original measurement scales [Narver, Slater, 1990; Deshpandé, Farley,

RMJ 17 (1): 71-96 (2019) 
Cluster descriptions, \%

\begin{tabular}{|c|c|c|c|c|c|}
\hline & \multicolumn{5}{|c|}{ Cluster } \\
\hline & $\mathbf{I}$ & II & III & IV & $\mathbf{V}$ \\
\hline \multicolumn{6}{|c|}{ Region } \\
\hline Federal cities & 74.7 & 68.4 & 64.5 & 70.8 & 62.1 \\
\hline Other regions & 25.3 & 31.6 & 35.5 & 29.2 & 37.9 \\
\hline \multicolumn{6}{|c|}{ Firm age } \\
\hline Less than 2 year & 8.4 & 1.8 & 12.9 & 5.6 & 17.2 \\
\hline $3-5$ years & 14.5 & 17.5 & 16.1 & 6.9 & 37.9 \\
\hline $6-10$ years & 20.5 & 17.5 & 22.6 & 18.1 & 10.3 \\
\hline $11-30$ years & 32.5 & 42.1 & 41.9 & 51.4 & 31.0 \\
\hline $\begin{array}{l}\text { More than } \\
30 \text { years }\end{array}$ & 24.1 & 21.1 & 6.5 & 18.1 & 3.4 \\
\hline \multicolumn{6}{|c|}{ Capital affiliation } \\
\hline Russian & 63.9 & 77.2 & 83.9 & 73.6 & 89.7 \\
\hline Joint & 20.5 & 15.8 & 9.7 & 12.5 & 6.9 \\
\hline Foreign & 15.7 & 7.0 & 6.5 & 13.9 & 3.4 \\
\hline \multicolumn{6}{|c|}{ Market } \\
\hline $\mathrm{B} 2 \mathrm{~B}$ & 36.1 & 56.1 & 51.6 & 44.4 & 55.2 \\
\hline $\begin{array}{l}\text { Both B2B and } \\
\text { B2C }\end{array}$ & 63.9 & 43.9 & 48.4 & 55.6 & 44.8 \\
\hline \multicolumn{6}{|c|}{ Market offer } \\
\hline Goods & 18.1 & 26.3 & 35.5 & 33.3 & 13.8 \\
\hline Services & 49.4 & 38.6 & 41.9 & 44.4 & 55.2 \\
\hline $\begin{array}{l}\text { Both goods and } \\
\text { services }\end{array}$ & 32.5 & 35.1 & 22.6 & 22.2 & 31.0 \\
\hline \multicolumn{6}{|c|}{ Firm size (number of employees) } \\
\hline Less than 100 & 47.0 & 61.4 & 51.6 & 38.9 & 72.4 \\
\hline $101-500$ & 15.7 & 22.8 & 19.4 & 27.8 & 17.2 \\
\hline $501-1000$ & 13.3 & 3.5 & 12.9 & 13.9 & - \\
\hline More than 1000 & 24.1 & 12.3 & 16.1 & 19.4 & 10.3 \\
\hline
\end{tabular}

Note: firms with Russian capital dominates in all clusters since the number of firms with Russian capital in the total sample exceed by several times firms with foreign and joint capital. Therefore, capital affiliation was not used in cluster descriptions, but nearly half of the firms (13 from 30 in the whole sample) with foreign capital are in cluster I.

Webster, 1993; Narver, Slater, MacLachlan, 2004]. The identified subdimensions help to understand the ways of how firms reflect the $\mathrm{CO}$ concept, prioritizing its different angles - e.g. focus on measuring customer satisfaction or being inconsistently applying corresponding values (thus, only "declaring” CO).
The overall findings from in-depth interviews demonstrate that respondents increasingly develop an understanding of the need for $\mathrm{CO}$ by their firms:

"The stable competitive advantages of the firm can be created thanks to constant CO".

Firm C, consulting 


\begin{abstract}
"Non-price factors of competition are beginning to play an increasing role, the firm which is ready to offer more value has an advantage".
\end{abstract}

Firm D, advertising agency

However, quantitative analyses have revealed substantial differences in firms' attitudes reagrding implementation of the $\mathrm{CO}$ concept. The identified differences demonstrated the presence of "truly customeroriented" firms as opposed to firm with "declared" CO. This result matches earlier findings (e.g. [Roersen, Kraaijenbrink, Groen, 2013]). The challenge for the customer side is that it might be substantially difficult, if not impossible, for the customer firms to realize the difference between a "true" (i.e. consistent, committed), and a "declared" (i.e. acknowledged, but failing support through regular practices and follow-up measures) CO. This information asymmetry is causing additional uncertainty for customer choice and shifts the burden of risks to the customer side.

A strong support was found for the existence of proactive $\mathrm{CO}$, which completely reflected its nature. This angle is perceived as a highly distinctive one, and can be a solid signal to the market about the commitment and consistency of CO implementation, helping differentiate between "truly customer-oriented" firms and firms only "declaring" these values. Other signals were found to be the significance of value creation (factor 3) and relationships with customers (factor 2). These angles might be further explored and integrated in $\mathrm{CO}$ measurement in the context of B2B markets.

The findings of the study provide for some comparison opportunities with the existing studies on CO in Russia. The focus on the "declared CO" was suggested in previous empirical and conceptual studies (e.g. [Roersen, Kraaijenbrink, Groen, 2013; Popov, Tretyak, 2014]) and confirmed by the results of our analysis. Similarly, the importance of competitor orientation as an alternative strategic focus was earlier raised in the study by [Smirnova et al., 2011], and is reflected in one of the factors identified in the current study as "orientation both for customers and competitors". The latter aspect may also help to investigate the relationship between the customer and competitors orientations as the core dimensions of MO in existing studies in developed markets (see Appendix 1). Lack of studies that consider the firm clusters does not provide for a direct comparison of the findings, however offer an agenda for further research. Further studies may potentially disintegrate well established existing concepts and measurement approaches into the dimensions that may capture identified latent angles of $\mathrm{CO}$. Existing studies on developed markets tend to consider $\mathrm{CO}$ as a drivers within the value chain, which also involve interfirm relationship in the B2B context. The revealed clustering of firms contributes to existing literature by suggesting the broader prospects for collaborative value creation. Our research helps to better understand the latent components of $\mathrm{CO}$ concept, as well as the types of the partners within the value chain that prioritize its different components.

We might conclude that current study initiates a discussion on revisiting well-established marketing concepts and their measurement approaches in B2B markets on example of $\mathrm{CO}$ in Russia. The results raise a question about the potential adaptation of existing scales in B2B market research and the further development of these scales with the specific focus on the value for customers and the customer relationships.

\section{Practical implications}

$\mathrm{CO}$ of B2B firms is examined using the example of the Russian emerging economy, which is undergoing various stages of transformation from a centrally-planned to a market economy. This market transformation involves substantial changes in managers' perceptions of core managerial concepts, including $\mathrm{MO}$ and $\mathrm{CO}$. The results of the study demonstrate the differences in

RMJ 17 (1): 71-96 (2019) 
understanding CO by researchers and marketers, which may cause different results from applying existing well-established measurement tools. Acknowledging these differences might be important in developing these measures in order to provide better diagnosing potential for the firms.

Our study shows that firms from Cluster II often demonstrate a so called "declared" $\mathrm{CO}$ and a superficial understanding of its core dimensions, when implementing the CO concept, they may not acknowledge their weaknesses and concerns about their processes and behavior [Roersen, Kraaijenbrink, Groen, 2013; Smirnova, Rebiazina, Frösén, 2018]. For example, the absence of a process for evaluating $\mathrm{CO}$ and customers satisfaction is possible:

"If customers pay for services, they are satisfied with our work".

Firm E, financial services

"We have no special KPIs for CO evaluation. If a customer is satisfied, we know it".

Firm $F$, consulting

The received cluster structure can help developing a practical tool for both $\mathrm{CO}$ development and management by B2B firms. The clusters demonstrate the prioritized strong aspects of $\mathrm{CO}$ and possible development opportunities we may use as a basis for managerial recommendations. For example, "truly customer-oriented firms" firms from cluster 1 might pay attention to ensuring $\mathrm{CO}$ on each business level for a more aligned strategy implementation. For "declarers" (cluster II) the priority might be to turn their $\mathrm{CO}$ vision into real procedures and matching KPIs. In case of "low customer-oriented" firms (cluster III) the priority would be to identify the reasons for the low $\mathrm{CO}$, as well as to understand the potential to improve required practices and values. The "strivers" (cluster IV) may aim for a more aligned approach to $\mathrm{CO}$ by leveraging the angles that are currently below the average. Finally, "CO newcomers" (cluster V) may struggle to systematically collect cus- tomer data and need to identify potential drivers to initiate CO-related activities.

\section{Research limitations}

Research limitations are common for the quantitative method. First, the sample of 272 firms cannot be representative for the general population of Russian B2B firms. Second, cluster analysis results show different approaches to $\mathrm{CO}$ implementation, but do not provide an in-depth explanation of the cluster specifics. To overcome this limitation, a small-scale qualitative research in the form of in-depth interviews was applied to investigate the specifics of $\mathrm{CO}$ of Russian B2B firms in detail. Further research on the Russian market should study all clusters in detail using qualitative methods, for example, multiple case study involving firms from each cluster.

\section{Directions for future research}

Additional research beyond the provided exploratory study is needed to quantitatively verify the conclusions and generalize the results. Further research is required to support the assumptions, generated by our data analysis. Further studies should focus on the structure and different dimensions of $\mathrm{CO}$ with the aim to develop an integrated $\mathrm{CO}$ scale that addresses specific issues of the transition economies such as Russia. Another potential research direction would be to conduct a similar study in another market context.

The following questions might be suggested for future research: Are there any differences in how B2B firms from emerging/ transition markets understand the core marketing constructs? How do factors such as capital structure, size and the location of the B2B firm (e.g. rural vs. urban location), their experience and expertise matter for defining and implementing $\mathrm{CO}$ ? How do the B2B firms interpret the value and behavioural/process side of CO? In particular, by claiming customer values do such firms imply that the right mindset already represents the required actions? 


\begin{tabular}{|c|c|c|c|c|c|c|c|c|c|}
\hline \multirow[b]{2}{*}{ Article } & \multirow[b]{2}{*}{$\begin{array}{c}\text { MO/ } \\
\text { CO }\end{array}$} & \multirow[b]{2}{*}{ 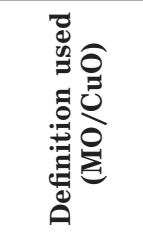 } & \multirow[b]{2}{*}{ 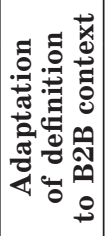 } & \multirow[b]{2}{*}{ 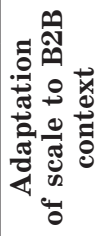 } & \multicolumn{5}{|c|}{ Methodology } \\
\hline & & & & & $\begin{array}{l}\text { Origin } \\
\text { of scale for } \\
\text { MO/CO }\end{array}$ & $\begin{array}{l}\text { Level } \\
\text { of } \\
\text { MO/ } \\
\text { CO }\end{array}$ & $\begin{array}{l}\text { Sample } \\
\text { (B2B/B2B } \\
+ \text { B2C) }\end{array}$ & $\begin{array}{l}\text { Context- } \\
\text { specific } \\
\text { settings }\end{array}$ & 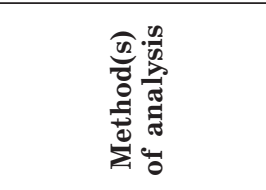 \\
\hline 1 & 2 & 3 & 4 & 5 & 6 & 7 & 8 & 9 & 10 \\
\hline $\begin{array}{l}\text { Bala- } \\
\text { krish- } \\
\text { nan, } \\
1996]\end{array}$ & $\begin{array}{l}\mathrm{CuO}, \\
\mathrm{MO}\end{array}$ & $\begin{array}{l}\text { [Narver, } \\
\text { Slater, } \\
\text { 1990] }\end{array}$ & No & Yes & $\begin{array}{l}\text { [Narver, Slater, } \\
\text { 1990; Saxe, } \\
\text { Weitz, 1982] }\end{array}$ & $\begin{array}{l}\text { Firm } \\
\text { level }\end{array}$ & B2B, 139 & $\begin{array}{l}\text { Machine } \\
\text { tool in- } \\
\text { dustry }\end{array}$ & $\begin{array}{l}\text { Exploratory fac- } \\
\text { tor analysis. } \\
\text { Regression } \\
\text { analysis. } \\
\text { ANOVA }\end{array}$ \\
\hline $\begin{array}{l}\text { [Bigné } \\
\text { et al., } \\
2004]\end{array}$ & MO & - & No & Yes & $\begin{array}{l}\text { [Narver, Slater, } \\
\text { 1990; Kohli, } \\
\text { Jarworski, } \\
\text { Kumar, 1993; } \\
\text { Deshpandé, Far- } \\
\text { ley, Webster, } \\
\text { 1993] }\end{array}$ & $\begin{array}{l}\text { Inter- } \\
\text { firm } \\
\text { level }\end{array}$ & $\begin{array}{l}\text { B2B, } 179 \\
\text { dyads }\end{array}$ & $\begin{array}{l}\text { Ceramic } \\
\text { tile sec- } \\
\text { tor }\end{array}$ & $\begin{array}{l}\text { Confirmatory } \\
\text { factor analysis. } \\
\text { Path analysis }\end{array}$ \\
\hline $\begin{array}{l}\text { [Cha- } \\
\text { kravar- } \\
\text { ty, } \\
\text { Kumar, } \\
\text { Grewal, } \\
\text { 2014] }\end{array}$ & $\mathrm{CuO}$ & $\begin{array}{l}\text { [Chakra- } \\
\text { varty, } \\
\text { Kumar, } \\
\text { Grewal } \\
\text { 2014] }\end{array}$ & Yes & Yes & $\begin{array}{l}\text { [Narver, Slater, } \\
\text { 1990] }\end{array}$ & \begin{tabular}{|l|} 
Firm \\
level
\end{tabular} & B2B, 109 & $\begin{array}{l}\text { Internet- } \\
\text { based } \\
\text { business- } \\
\text { to-busi- } \\
\text { ness } \\
\text { platform } \\
\text { firms }\end{array}$ & $\begin{array}{l}\text { Confirmatory } \\
\text { factor analysis. } \\
\text { Latent class } \\
\text { regression } \\
\text { method }\end{array}$ \\
\hline $\begin{array}{l}\text { [Desh- } \\
\text { pandé, } \\
\text { Farley, } \\
\text { Web- } \\
\text { ster, } \\
2000]\end{array}$ & MO & $\begin{array}{l}\text { [Desh- } \\
\text { pandé, } \\
\text { Farley, } \\
\text { Webster, } \\
\text { 1993] }\end{array}$ & Yes & Yes & $\begin{array}{l}\text { [Deshpand, } \\
\text { Farley, Webster, } \\
\text { 1993] }\end{array}$ & $\begin{array}{l}\text { Inter- } \\
\text { firm } \\
\text { level }\end{array}$ & $\begin{array}{l}\text { B2B, } 592 \\
(148 \\
\text { quadrads } \\
\text { of firms) }\end{array}$ & \begin{tabular}{|l|} 
Cross- \\
national \\
sample
\end{tabular} & $\begin{array}{l}\text { MANOVA. } \\
\text { ANOVA. } \\
\text { Segmented } \\
\text { regression } \\
\text { analysis }\end{array}$ \\
\hline $\begin{array}{l}\text { [Frösén } \\
\text { et al., } \\
2016]\end{array}$ & MO & \begin{tabular}{|l|} 
[Narver, \\
Slater, \\
1990]
\end{tabular} & No & No & $\begin{array}{l}\text { [Narver, Slater, } \\
1990]\end{array}$ & \begin{tabular}{|l|} 
Firm \\
level
\end{tabular} & B2B, 140 & $\begin{array}{l}\text { The busi- } \\
\text { ness cy- } \\
\text { cles (eco- } \\
\text { nomic } \\
\text { upturn } \\
\text { and } \\
\text { down- } \\
\text { turn) }\end{array}$ & \begin{tabular}{|l|} 
Principal compo- \\
nent analysis. \\
Confirmatory \\
factor analysis. \\
Longitudinal \\
regression \\
analysis. \\
Fuzzy set Quali- \\
tative Compa- \\
rative Analysis
\end{tabular} \\
\hline
\end{tabular}


Appendix 1

\begin{tabular}{|c|c|c|c|}
\hline 总 & Output & 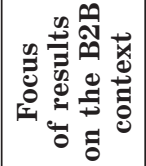 & Key findings \\
\hline 11 & 12 & 13 & 14 \\
\hline USA & $\begin{array}{l}\text { Performance (subjective): } \\
\text { - last year's net profit before } \\
\text { tax; } \\
\text { - last year's after tax return on } \\
\text { total assets; } \\
\text { - after tax return on total as- } \\
\text { sets for the last three years; } \\
\text { - net profit before tax over } \\
\text { the last three years; } \\
\text { - customer retention rate; } \\
\text { - repeat business generated } \\
\text { from customers }\end{array}$ & Yes & $\begin{array}{l}\text { MO has a strong impact on performance } \\
\text { (positive and significant) }\end{array}$ \\
\hline Spain & $\begin{array}{l}\text { Distributor's satisfaction. } \\
\text { Mediators: } \\
\text { - reward power; } \\
\text { - coercive power; } \\
\text { - expert power; } \\
\text { - referent power }\end{array}$ & Yes & $\begin{array}{l}\text { The manufacturers' MO has a negative effect } \\
\text { on their expert power and a positive effect on } \\
\text { their reward power, but not on their referent } \\
\text { power nor on their power of coercion. } \\
\text { The reward, expert and referent powers of the } \\
\text { manufacturer do have a positive and signifi- } \\
\text { cant effect on the distributor's satisfaction. } \\
\text { The power of coercion influences this satisfac- } \\
\text { tion in a negative way }\end{array}$ \\
\hline- & $\begin{array}{l}\text { Performance: return on invest- } \\
\text { ments, sales, profits, growth, } \\
\text { market share }\end{array}$ & Yes & $\begin{array}{l}\text { B2B platform firms that align their depen- } \\
\text { dence management strategy (as reflected in } \\
\text { their CO efforts) to their particular depen- } \\
\text { dent situation (as captured through customer } \\
\text { concentration) in a selective fashion have } \\
\text { superior performance }\end{array}$ \\
\hline $\begin{array}{l}\text { Mix coun- } \\
\text { tries }\end{array}$ & $\begin{array}{l}\text { Performance (subjective): profits, } \\
\text { size, growth, share }\end{array}$ & No & $\begin{array}{l}\text { MO has a positive but insignificant impact } \\
\text { on performance }\end{array}$ \\
\hline Finland & $\begin{array}{l}\text { Performance (objective): return } \\
\text { on investment }\end{array}$ & Yes & $\begin{array}{l}\text { The impact of MO increases especially during } \\
\text { a downturn, with interfunctional coordination } \\
\text { boosting firm performance and, conversely, } \\
\text { competitor orientation becoming even detri- } \\
\text { mental. MO has a particularly strong impact } \\
\text { on performance among B2B service firms }\end{array}$ \\
\hline
\end{tabular}




\begin{tabular}{|c|c|c|c|c|c|c|c|c|c|}
\hline 1 & 2 & 3 & 4 & 5 & 6 & 7 & 8 & 9 & 10 \\
\hline $\begin{array}{l}\text { [Gou- } \\
\text { naris, } \\
\text { Avloni- } \\
\text { tis, } \\
\text { 2001] }\end{array}$ & MO & - & No & No & $\begin{array}{l}\text { [Hooley, Lynch, } \\
\text { Shepherd, 1990; } \\
\text { Kohli, Jaworski, } \\
\text { 1990] }\end{array}$ & $\begin{array}{l}\text { Firm } \\
\text { level }\end{array}$ & $\begin{array}{l}\text { B2B }+ \\
\text { B2C, } 444\end{array}$ & $\begin{array}{l}\text { Cross } \\
\text { industry } \\
\text { sample } \\
\text { (goods) }\end{array}$ & $\begin{array}{l}\text { Principal } \\
\text { Components. } \\
\text { Factor analysis. } \\
\text { Cluster analysis. } \\
\text { Chi-square anal- } \\
\text { ysis. } \\
\text { T-tests. } \\
\text { Multivariate } \\
\text { analysis }\end{array}$ \\
\hline $\begin{array}{l}{[\text { Guo, }} \\
\text { Wang, } \\
2015]\end{array}$ & MO & $\begin{array}{l}\text { [Narver, } \\
\text { Slater, } \\
1990]\end{array}$ & No & No & $\begin{array}{l}\text { [Narver, Slater, } \\
\text { 1990; Han, } \\
\text { Kim, Srivastava, } \\
1998 \text { ] }\end{array}$ & $\begin{array}{l}\text { Firm } \\
\text { level }\end{array}$ & B2B, 279 & $\begin{array}{l}\text { Indust- } \\
\text { rial } \\
\text { manufac- } \\
\text { turing } \\
\text { firms }\end{array}$ & $\begin{array}{l}\text { Common method } \\
\text { variance analy- } \\
\text { sis. } \\
\text { Exploratory fac- } \\
\text { tor analysis. } \\
\text { Confirmatory } \\
\text { factor analysis. } \\
\text { Hierarchical } \\
\text { moderator re- } \\
\text { gression analysis }\end{array}$ \\
\hline $\begin{array}{l}{[\text { Hsieh, }} \\
\text { Chiu, } \\
\text { Hsu, } \\
2008]\end{array}$ & MO & $\begin{array}{l}\text { [Narver, } \\
\text { Slater, } \\
1990]\end{array}$ & No & No & $\begin{array}{l}\text { [Narver, Slater, } \\
1990]\end{array}$ & $\begin{array}{l}\text { Firm } \\
\text { level }\end{array}$ & $\begin{array}{l}\text { B2B }+ \\
\text { B2C, } 200\end{array}$ & $\begin{array}{l}\text { Cross } \\
\text { industry } \\
\text { sample }\end{array}$ & $\begin{array}{l}\text { Principal factor } \\
\text { analysis. } \\
\text { Confirmatory } \\
\text { factor analysis. } \\
\text { Regression anal- } \\
\text { ysis }\end{array}$ \\
\hline $\begin{array}{l}{[\text { Pel- }} \\
\text { ham, } \\
\text { 1997] }\end{array}$ & MO & $\begin{array}{l}\text { [Narver, } \\
\text { Slater, } \\
\text { 1990] }\end{array}$ & No & Yes & $\begin{array}{l}\text { [Narver, Slater, } \\
\text { 1990; Kohli, } \\
\text { Jaworski, 1990] }\end{array}$ & $\begin{array}{l}\text { Firm } \\
\text { level }\end{array}$ & $\mathrm{B} 2 \mathrm{~B}, 160$ & $\begin{array}{l}\text { Small in- } \\
\text { dustrial } \\
\text { manufac- } \\
\text { turing } \\
\text { firms }\end{array}$ & $\begin{array}{l}\text { Analysis of par- } \\
\text { tial correlations. } \\
\text { Multiple regres- } \\
\text { sion analysis }\end{array}$ \\
\hline $\begin{array}{l}\text { [Perry, } \\
\text { Shao, } \\
2005]\end{array}$ & $\begin{array}{l}\mathrm{CuO} \\
\mathrm{MO}\end{array}$ & $\begin{array}{l}\text { [Kohli, } \\
\text { Jawor- } \\
\text { ski, } \\
\text { Kumar, } \\
\text { 1993] }\end{array}$ & No & Yes & $\begin{array}{l}\text { [Kohli, } \\
\text { Jaworski, } \\
\text { Kumar, 1993] }\end{array}$ & $\begin{array}{l}\text { Firm } \\
\text { level }\end{array}$ & B2B, 106 & $\begin{array}{l}\text { Subsi- } \\
\text { diaries } \\
\text { of } \\
\text { U.S.- } \\
\text { based } \\
\text { Internet } \\
\text { adver- } \\
\text { tising } \\
\text { agencies }\end{array}$ & $\begin{array}{l}\text { Exploratory fac- } \\
\text { tor analysis. } \\
\text { Regression anal- } \\
\text { ysis }\end{array}$ \\
\hline
\end{tabular}


Appendix 1 (continued)

\begin{tabular}{|c|c|c|c|}
\hline 11 & 12 & 13 & 14 \\
\hline Greece & $\begin{array}{l}\text { Performance (subjective): market } \\
\text { share and return on investment }\end{array}$ & Yes & $\begin{array}{l}\text { Industrial goods companies, when compared } \\
\text { to consumer goods ones, are less market ori- } \\
\text { ented, in terms of both culture and behavior }\end{array}$ \\
\hline USA & $\begin{array}{l}\text { Customer satisfaction (mediator), } \\
\text { customer retention }\end{array}$ & Yes & $\begin{array}{l}\text { Both } \mathrm{CO} \text { and competitor orientation of manu- } \\
\text { facturing firms are positively (and significant- } \\
\text { ly) related to B2B customer satisfaction, } \\
\text { while interfunctional coordination is not } \\
\text { related to satisfaction. } \\
\text { Only CO has a direct impact on B2B customer } \\
\text { retention. Competitor orientation has an indi- } \\
\text { rect effect on customer retention }\end{array}$ \\
\hline Taiwan & $\begin{array}{l}\text { Customer satisfaction. } \\
\text { Mediators: flexibility, relation- } \\
\text { ship-specific adaptations }\end{array}$ & No & $\begin{array}{l}\text { CO, competitor orientation, and interfunc- } \\
\text { tional coordination relate differently to the } \\
\text { flexibility and relationship-specific adaptation } \\
\text { during the relationship lifecycle. } \\
\text { Accommodation strategies significantly medi- } \\
\text { ate the effects of the three market orienta- } \\
\text { tion components on customer satisfaction }\end{array}$ \\
\hline USA & $\begin{array}{l}\text { Performance (subjective): firm } \\
\text { effectiveness (relative product } \\
\text { quality, new product success, } \\
\text { and customer retention), } \\
\text { growth/share, profitability }\end{array}$ & Yes & $\begin{array}{l}\text { The positive MO-performance relationship is } \\
\text { strongest in differentiated markets (charac- } \\
\text { terized by low levels of customer differentia- } \\
\text { tion and high levels of product differentia- } \\
\text { tion). } \\
\text { The positive relationship between MO and } \\
\text { firm effectiveness is much stronger in seg- } \\
\text { mented markets (with high customer differen- } \\
\text { tiation, but low product differentiation), com- } \\
\text { pared to commodity markets }\end{array}$ \\
\hline $\begin{array}{l}\text { Mix coun- } \\
\text { tries }\end{array}$ & $\begin{array}{l}\text { Performance (subjective): new } \\
\text { client revenue, existing client } \\
\text { revenue, profitability, agency } \\
\text { image, responsiveness to existing } \\
\text { clients, competitive advantage } \\
\text { and the ability to attract new } \\
\text { clients }\end{array}$ & No & $\begin{array}{l}\text { Client orientation had a significant, } \\
\text { but negative relationship with performance }\end{array}$ \\
\hline
\end{tabular}




\begin{tabular}{|c|c|c|c|c|c|c|c|c|c|}
\hline 1 & 2 & 3 & 4 & 5 & 6 & 7 & 8 & 9 & 10 \\
\hline $\begin{array}{l}\text { [Sanzo } \\
\text { et al., } \\
2003]\end{array}$ & MO & $\begin{array}{l}\text { [Dalgic, } \\
\text { 1998] }\end{array}$ & Yes & Yes & $\begin{array}{l}\text { [Narver, Slater, } \\
\text { 1990; Ruekert, } \\
\text { 1992; Kohli, } \\
\text { Jaworski, } \\
\text { Kumar 1993; } \\
\text { Diarnanto- } \\
\text { poulos, Hart, } \\
\text { 1993; } \\
\text { Deshpandé, } \\
\text { Farley, Webster, } \\
\text { 1993; Deng, } \\
\text { Dart, 1994; } \\
\text { Deshpandé, } \\
\text { Farley, 1998; } \\
\text { Pelham, Wilson, } \\
\text { 1996] }\end{array}$ & $\begin{array}{l}\text { Inter- } \\
\text { firm } \\
\text { level }\end{array}$ & B2B, 141 & $\begin{array}{l}\text { Cross } \\
\text { industry } \\
\text { sample }\end{array}$ & $\begin{array}{l}\text { The robust maxi- } \\
\text { mum likelihood } \\
\text { method }\end{array}$ \\
\hline $\begin{array}{l}\text { [Sigu- } \\
\text { aw, } \\
\text { Simp- } \\
\text { son, } \\
\text { Baker, } \\
\text { 1998] }\end{array}$ & MO & $\begin{array}{l}{[\text { Kohli, }} \\
\text { Jawor- } \\
\text { ski, } \\
1990]\end{array}$ & No & Yes & $\begin{array}{l}\text { [Kohli, } \\
\text { Jaworski, 1990] }\end{array}$ & $\begin{array}{l}\text { Inter- } \\
\text { firm } \\
\text { level }\end{array}$ & $\begin{array}{l}\text { B2B, } 358 \\
(179 \text { dyads } \\
\text { of firms })\end{array}$ & $\begin{array}{l}\text { Cross } \\
\text { industry } \\
\text { sample }\end{array}$ & Path analysis \\
\hline $\begin{array}{l}\text { [Singh, } \\
\text { Ranch- } \\
\text { hod, } \\
2004]\end{array}$ & MO & $\begin{array}{l}\text { [Singh, } \\
\text { Ranch- } \\
\text { hod, } \\
\text { 2004] }\end{array}$ & Yes & Yes & $\begin{array}{l}\text { [Deng, Dart, } \\
\text { 1994; Jaworski, } \\
\text { Kohli, 1993; } \\
\text { Narver, Slater, } \\
\text { 1990] }\end{array}$ & $\begin{array}{l}\text { Firm } \\
\text { level }\end{array}$ & B2B, 93 & $\begin{array}{l}\text { Machine } \\
\text { tool } \\
\text { industry }\end{array}$ & $\begin{array}{l}\text { Exploratory fac- } \\
\text { tor analysis. } \\
\text { Multiple regres- } \\
\text { sion analysis. } \\
\text { ANOVA }\end{array}$ \\
\hline $\begin{array}{l}{[\text { Zig- }} \\
\text { gers, } \\
\text { Hense- } \\
\text { ler, } \\
2016]\end{array}$ & $\mathrm{CuO}$ & $\begin{array}{l}\text { [Day, } \\
1994]\end{array}$ & No & Yes & $\begin{array}{l}\text { [Chen, Paulraj, } \\
\text { 2004a] }\end{array}$ & $\begin{array}{l}\text { Firm } \\
\text { level }\end{array}$ & $\begin{array}{l}\mathrm{B} 2 \mathrm{~B}+ \\
\mathrm{B} 2 \mathrm{C}, 176\end{array}$ & $\begin{array}{l}\text { Cross } \\
\text { industry } \\
\text { sample }\end{array}$ & $\begin{array}{l}\text { Partial least } \\
\text { squares path } \\
\text { modeling }\end{array}$ \\
\hline
\end{tabular}

$\mathrm{N}$ ot e: the main direction of $\mathrm{CO}$ learning on the developed B2B market is it influence on business performance. Also researchers revealed the relations between $\mathrm{CO}$ and relationships value chain, customer satisfaction and customer retention. For companies from developed B2B markets it is typical to consider CO in frame of the 
Appendix 1 (continued)

\begin{tabular}{|c|c|c|c|}
\hline 11 & 12 & 13 & 14 \\
\hline Spain & $\begin{array}{l}\text { Continuity of the relationship } \\
\text { with the supplier. } \\
\text { Mediators: effective communica- } \\
\text { tion, affective commitment, } \\
\text { trust, satisfaction }\end{array}$ & Yes & $\begin{array}{l}\text { There is a positive (and significant) indirect } \\
\text { relationship between the buyer's cultural } \\
\text { market orientation and the maintaining } \\
\text { of long term relationships with a supplier }\end{array}$ \\
\hline USA & $\begin{array}{l}\text { Satisfaction with financial per- } \\
\text { formance. } \\
\text { Mediators: distributor's trust, } \\
\text { cooperative norms, commitment } \\
\text { to the supplier }\end{array}$ & Yes & $\begin{array}{l}\text { Supplier's market-oriented behaviors directly } \\
\text { or indirectly affect all the channel relation- } \\
\text { ship factors examined from the distributor's } \\
\text { perspective, specifically the distributor's mar- } \\
\text { ket orientation, trust, cooperative norms, } \\
\text { commitment, and satisfaction with financial } \\
\text { performance }\end{array}$ \\
\hline UK & $\begin{array}{l}\text { Performance (subjective): cus- } \\
\text { tomer retention, market share, } \\
\text { new product success, return on } \\
\text { investment, sales growth }\end{array}$ & Yes & $\begin{array}{l}\text { Customer, competitor and satisfaction orien- } \\
\text { tations have a significant and positive effect } \\
\text { on business performance. } \\
\text { Responsiveness within the department does } \\
\text { not have a significant and positive effect on } \\
\text { business performance }\end{array}$ \\
\hline Netherlands & $\begin{array}{l}\text { Performance (subjective): } \\
\text { volume flexibility, delivery speed, } \\
\text { delivery reliability/dependability, } \\
\text { product conformance to specifica- } \\
\text { tions, rapid confirmation of cus- } \\
\text { tomer orders, rapid handling of } \\
\text { customer complaints, customer } \\
\text { satisfaction }\end{array}$ & No & $\begin{array}{l}\text { CO has a significant and positive effect on } \\
\text { firm performance. } \\
\text { The findings indicate that } \mathrm{CO} \text { and supply-base } \\
\text { orientation are complementary strategic } \\
\text { assets that contribute to superior perfor- } \\
\text { mance }\end{array}$ \\
\hline
\end{tabular}

value chain creation, that means that companies are ready to develop CO not only on the company level but on the level of the whole chain. As CO on the emerging markets is lower developed there are just a few numbers of companies, which are ready to expand $\mathrm{CO}$ to the level of value chain creation. 


\section{Appendix 2}

\section{SAMPLE DESCRIPTION}

\begin{tabular}{|c|c|c|}
\hline Description & $N$ of firms & $\%$ of firms \\
\hline \multicolumn{3}{|c|}{ Region } \\
\hline Federal cities & 190 & 69.9 \\
\hline Other regions & 82 & 30.1 \\
\hline \multicolumn{3}{|c|}{ Firm age } \\
\hline Less than 2 year & 21 & 7.7 \\
\hline $3-5$ years & 43 & 15.8 \\
\hline $6-10$ years & 50 & 18.4 \\
\hline $11-30$ years & 110 & 40.4 \\
\hline More than 30 years & 48 & 17.6 \\
\hline \multicolumn{3}{|c|}{ Capital affiliation } \\
\hline Russian & 202 & 74.3 \\
\hline Joint & 40 & 14.7 \\
\hline Foreign & 30 & 11.0 \\
\hline \multicolumn{3}{|c|}{ Market } \\
\hline $\mathrm{B} 2 \mathrm{~B}$ & 126 & 46.3 \\
\hline Both B2B, and B2C & 146 & 53.7 \\
\hline \multicolumn{3}{|c|}{ Market offer } \\
\hline Goods & 69 & 25.4 \\
\hline Services & 124 & 45.6 \\
\hline Both goods and services & 79 & 29.0 \\
\hline \multicolumn{3}{|c|}{ Firm size (number of employees) } \\
\hline Less than 100 & 139 & 51.1 \\
\hline $101-500$ & 57 & 21.0 \\
\hline $501-1000$ & 27 & 9.9 \\
\hline More than 1000 & 49 & 18.0 \\
\hline
\end{tabular}

Appendix 3

DESCRIPTIVE STATISTICS

\begin{tabular}{c|l|c|c|c|c|c|c}
\hline \multirow{2}{*}{ Indicator } & \multicolumn{1}{|c|}{ Indicator label } & \multicolumn{2}{|c|}{ Item statistics } & \multicolumn{4}{|c}{ Item total statistics } \\
\cline { 3 - 8 } & & Mean & $\begin{array}{c}\text { Standard } \\
\text { deviation }\end{array}$ & $\begin{array}{c}\text { Scale } \\
\text { means } \\
\text { if item } \\
\text { deleted }\end{array}$ & $\begin{array}{c}\text { Scale } \\
\text { variance } \\
\text { if item } \\
\text { deleted }\end{array}$ & $\begin{array}{c}\text { Corrected } \\
\text { item total } \\
\text { correla- } \\
\text { tion }\end{array}$ & $\begin{array}{c}\text { Cronbach's } \\
\text { Alpha } \\
\text { if item } \\
\text { deleted }\end{array}$ \\
\hline $\mathbf{1}$ & $\mathbf{2}$ & $\mathbf{4}$ & $\mathbf{4}$ & $\mathbf{5}$ & $\mathbf{6}$ & $\mathbf{7}$ & $\mathbf{8}$ \\
\hline $\mathrm{K} 1$ & We are committed to customer & 4.38 & 0.83 & 87.76 & 223.75 & 0.52 & 0.92 \\
\hline $\mathrm{K} 2$ & We create customer value & 4.48 & 0.74 & 87.66 & 223.65 & 0.59 & 0.91 \\
\hline $\mathrm{K} 3$ & We understand customer needs & 4.37 & 0.76 & 87.77 & 224.04 & 0.56 & 0.91 \\
\hline $\mathrm{K} 4$ & $\begin{array}{l}\text { Customer satisfaction is one of our } \\
\text { objectives }\end{array}$ & 4.36 & 0.91 & 87.78 & 221.74 & 0.54 & 0.91 \\
\hline
\end{tabular}


Appendix 3 (continued)

\begin{tabular}{|c|c|c|c|c|c|c|c|}
\hline 1 & 2 & 3 & 4 & 5 & 6 & 7 & 8 \\
\hline K5 & We offered after-sales service & 4.14 & 1.03 & 88.00 & 219.15 & 0.56 & 0.91 \\
\hline K6 & We measure customer satisfaction & 3.58 & 1.30 & 88.56 & 211.38 & 0.64 & 0.91 \\
\hline K7 & $\begin{array}{l}\text { We help our customers anticipate } \\
\text { developments in their markets }\end{array}$ & 3.82 & 1.20 & 88.32 & 218.18 & 0.50 & 0.92 \\
\hline K8 & $\begin{array}{l}\text { We continuously try to discover } \\
\text { additional needs of our customers } \\
\text { of which they are unaware }\end{array}$ & 3.89 & 1.19 & 88.25 & 214.00 & 0.63 & 0.91 \\
\hline K9 & $\begin{array}{l}\text { We incorporate solutions to unarticu- } \\
\text { lated customer needs in our new } \\
\text { products and services }\end{array}$ & 4.20 & 1.03 & 87.94 & 218.39 & 0.59 & 0.91 \\
\hline K10 & $\begin{array}{l}\text { We brainstorm on how customers use } \\
\text { our products and services }\end{array}$ & 3.55 & 1.30 & 88.59 & 214.60 & 0.55 & 0.91 \\
\hline K11 & $\begin{array}{l}\text { We innovate even at the risk of } \\
\text { making our own products obsolete }\end{array}$ & 3.60 & 1.28 & 88.54 & 212.97 & 0.61 & 0.91 \\
\hline K12 & $\begin{array}{l}\text { We search for opportunities in areas } \\
\text { where customers have a difficult time } \\
\text { expressing their needs }\end{array}$ & 3.62 & 1.22 & 88.52 & 214.14 & 0.61 & 0.91 \\
\hline K13 & $\begin{array}{l}\text { We work closely with lead users who } \\
\text { try to recognize customer needs } \\
\text { months or even years before the major- } \\
\text { ity of the market may recognize them }\end{array}$ & 3.13 & 1.29 & 89.01 & 213.90 & 0.58 & 0.91 \\
\hline K14 & $\begin{array}{l}\text { We extrapolate key trends to gain in- } \\
\text { sight into what users in a current } \\
\text { market will need in the future }\end{array}$ & 3.89 & 1.05 & 88.25 & 220.37 & 0.51 & 0.92 \\
\hline K15 & $\begin{array}{l}\text { We constantly monitor our level } \\
\text { of commitment and orientation to } \\
\text { serving customer needs }\end{array}$ & 3.26 & 1.23 & 88.88 & 212.43 & 0.65 & 0.91 \\
\hline K16 & $\begin{array}{l}\text { Our strategy for competitive advan- } \\
\text { tage is based on our understanding } \\
\text { of customers' needs }\end{array}$ & 4.01 & 0.98 & 88.13 & 218.61 & 0.62 & 0.91 \\
\hline K17 & $\begin{array}{l}\text { We are more customer focused than } \\
\text { our competitors }\end{array}$ & 3.85 & 0.95 & 88.29 & 221.20 & 0.54 & 0.91 \\
\hline K18 & $\begin{array}{l}\text { I believe this business exist primarily } \\
\text { to serve customers }\end{array}$ & 4.04 & 1.03 & 88.10 & 221.52 & 0.48 & 0.92 \\
\hline K19 & $\begin{array}{l}\text { Data on customer satisfaction are } \\
\text { disseminated at all levels of this } \\
\text { business unit on a regular basis }\end{array}$ & 3.26 & 1.31 & 88.88 & 213.34 & 0.58 & 0.91 \\
\hline $\mathrm{K} 20$ & We know our competitors well & 4.19 & 0.96 & 87.95 & 226.86 & 0.33 & 0.92 \\
\hline K21 & $\begin{array}{l}\text { We have a good sense of how our } \\
\text { customers value our products and } \\
\text { services }\end{array}$ & 3.93 & 0.91 & 88.21 & 222.50 & 0.51 & 0.92 \\
\hline $\mathrm{K} 22$ & $\begin{array}{l}\text { We compete primarily based on } \\
\text { product or service differentiation }\end{array}$ & 3.46 & 1.20 & 88.68 & 220.63 & 0.43 & 0.92 \\
\hline $\mathrm{K} 23$ & $\begin{array}{l}\text { The customer's interest should always } \\
\text { come first, ahead of the owners' }\end{array}$ & 3.19 & 1.17 & 88.94 & 220.17 & 0.45 & 0.92 \\
\hline K24 & $\begin{array}{l}\text { Our products/services are the best } \\
\text { in the business }\end{array}$ & 3.93 & 0.97 & 88.21 & 222.65 & 0.48 & 0.92 \\
\hline
\end{tabular}




\section{REFERENCES}

Adhikari A., Gill M. S. 2011. Impact of resources, capabilities and technology on market orientation of Indian B2B firms. Journal of Services Research 11 (2): 75-98.

Agarwal S., Krishna Erramilli M., Dev C. S. 2003. Market orientation and performance in service firms: Role of innovation. Journal of Services Marketing 17 (1): 68-82.

Akimova I. 2000. Development of market orientation and competitiveness of Ukrainian firms. European Journal of Marketing 34 (9/10): 1128-1148.

Babu M. M. 2018. Impact of firm's customer orientation on performance: The moderating role of interfunctional coordination and employee commitment. Journal of Strategic Marketing 26 (8): 702-722.

Balakrishnan S. 1996. Benefits of customer and competitive orientations in industrial markets. Industrial Marketing Management 25 (4): 257-269.

Bigné J ., Blesa A., Küster I., Andreu L. 2004. Market orientation: An antecedent to the industrial manufacturer's power. European Journal of Marketing 38 (1/2): 175-193.

Bommaraju R., Ahearne M., Krause R., Tirunillai S. 2019. Does a customer on the board of directors affect business-to-business firm performance? Journal of Marketing 83 (1): 8-23.

Chakravarty A., Kumar A., Grewal R. 2014. Customer orientation structure for internet-based business-to-business platform firms. Journal of Marketing 78 (5): 1-23.

Chan Hung Ngai J., Ellis P. 1998. Market orientation and business performance: Some evidence from Hong Kong. International Marketing Review 15 (2): 119-139.

Charterina J., Basterretxea I., Landeta J. 2016. Types of embedded ties in buyersupplier relationships and their combined effects on innovation performance. Journal of Business \& Industrial Marketing 31 (2): $152-163$.

Chung J.-E., Huang Y., Jin B., Sternquist B. 2011. The impact of market orientation on Chinese retailers' channel relationships.
Journal of Business \& Industrial Marketing 26 (1): 14-25.

Coley L. S., Mentzer J. T., Cooper M.C. 2010. Is "Consumer Orientation" a dimension of market orientation in consumer markets? Journal of Marketing Theory and Practice 18 (2): 141-154.

Dalgic T. 1998. Dissemination of market orientation in Europe: A conceptual and historical evaluation. International Marketing Review 15 (1): 45-60.

Day G.S. 1994. The capabilities of marketdriven organizations. Journal of Marketing 58 (4): 37-52.

Deshpandé R., Farley J.U. 1998. Measuring market orientation: Generalization and synthesis. Journal of Market-focused Management 2 (3): 213-232.

Deshpandé R., Farley J.U., Webster Jr.F.E. 1993. Corporate culture, customer orientation, and innovativeness in Japanese firms: A quadrad analysis. Journal of Marketing 57 (1): $23-37$.

Deshpandé R., Farley J. U., Webster Jr.F.E. 2000. Triad lessons: Generalizing results on high performance firms in five businessto-business markets. International Journal of Research in Marketing 17 (4): 353362.

Ellis P.D. 2006. Market orientation and performance: A meta-analysis and cross-national comparisons. Journal of Management Studies 43 (5): 1089-1107.

Farias P., Torres E., Cortez R.M. 2017. A new model for measuring salesperson lifetime value. Journal of Business \& Industrial Marketing 32 (2): 274-281.

Farley J. U., Deshpandé R. 2006. Charting the evolution of Russian firms from Soviet "producer orientation" to contemporary "market orientation". Journal of Global Marketing 19 (2): 7-26.

Frösén J., Luoma J., Jaakkola M., Tikkanen H., Aspara J. 2016. What counts versus what can be counted: The complex interplay of market orientation and marketing performance measurement. Journal of Marketing 80 (3): 60-78. 
Golden P.A., Johnson D. M., Smith J.R. 1995. Strategic orientation and marketing strategies in transition economies: A study of Russian firms. Journal of Strategic Marketing 3 (1): 1-22.

Gounaris S.P., Avlonitis G.J. 2001. Market orientation development: A comparison of industrial vs consumer goods companies. Journal of Business \& Industrial Market ing 16 (5): 354-381.

Gray B. J., Hooley G. J. 2002. Guest editorial: Market orientation and service firm performance - a research agenda. European Journal of Marketing 36 (9/10): 980-989.

Greenley G.E. 1995. Forms of market orientation in UK companies. Journal of Management Studies 32 (1): 47-66.

Guo C., Wang Y. 2015. How manufacturer market orientation influences B2B customer satisfaction and retention: Empirical investigation of the three market orientation components. Journal of Business \& Industrial Marketing 30 (2): 182193.

Hajjat M. M. 2002. Customer orientation: Construction and validation of the CUSTOR scale. Marketing Intelligence \& Planning 20 (7): 428-441.

Han J.K., Kim N., Srivastava R. K. 1998. Market orientation and organizational performance: Is innovation a missing link? Journal of Marketing 62 (4): 30-45.

Heins R. A. 2000. Market orientation: Toward an integrated framework. Academy of Mar keting Science Review 4 (1): 1-5.

Herhausen D., De Luca L. M., Weibel M. 2018. The interplay between employee and firm customer orientation: Substitution effect and the contingency role of performancerelated rewards. British Journal of Management 29 (3): 534-553.

Homburg C., Pflesser C. 2000. A multiplelayer model of market-oriented organizational culture: Measurement issues and performance outcomes. Journal of Market ing Research 37 (4): 449-462.

Hooley G.J., Lynch J.E., Shepherd J. 1990. The marketing concept: Putting the theory into practice. European Journal of Market ing 24 (9): 7-24.
Hsieh Y.-C., Chiu H.-C., Hsu Y.-C. 2008. Supplier market orientation and accommodation of the customer in different relationship phases. Industrial Marketing Management 37 (4): 380-393.

Iyer P., Davari A., Zolfagharian M., Paswan A. 2018. Market orientation, positioning strategy and brand performance. Industrial Marketing Management. [Electronic resource]. https://doi.org/10.1016/j.indmarman.2018.11.004

Jacob F. 2006. Preparing industrial suppliers for customer integration. Industrial Marketing Management 35 (1): 45-56.

Jaworski B. J., Kohli A. K. 1993. Market orientation: Antecedents and consequences. Journal of Marketing 57 (3): 53-70.

Kaynak E., Kara A. 2004. Market orientation and organizational performance: A comparison of industrial versus consumer companies in mainland China using market orientation scale (MARKOR). Industrial Marketing Management 33 (8): 743-753.

Khan A., Zolkiewski J., Murphy J. 2016. Favour and opportunity: Renqing in Chinese business relationships. Journal of Business \& Industrial Marketing 31 (2): 183192.

Kirca A.H., Jayachandran S., Bearden W.O. 2005. Market orientation: A meta-analytic review and assessment of its antecedents and impact on performance. Journal of Marketing 69 (2): 24-41.

Kohli A. K., Jaworski B.J. 1990. Market orientation: The construct, research propositions, and managerial implications. Journal of Marketing 54 (2): 1-18.

Kohli A.K., Jaworski B.J., Kumar A. 1993. MARKOR: A measure of market orientation. Journal of Marketing Research 30 (4): 467-477.

Kraaijenbrink J., Roersen M.J., Groen A.J. 2009. Testing the content validity of the Narver \& Slater market orientation scale in transition economies. In: Academy of Management Proceedings (Vol. 2009, No.1, p.1-6). Briarcliff Manor, NY 10510: Academy of Management.

Liao S.H., Chang W.J., Wu C.C., Katrichis J.M. 2011. A survey of market orientation 
research (1995-2008). Industrial Marketing Management 40 (2): 301-310.

Lussier B., Hall Z. R. 2018. Cooperation in B2B relationships: Factors that influence customers' perceptions of salesperson cooperation. Industrial Marketing Management 69: 209-220.

Marinov M., Cox T., Avlonitis G. J., Kouremenos T. 1993. Marketing approaches in Bulgaria. European Journal of Marketing 27 (11/12): 34-46.

Matsuno K., Mentzer J.T., Rentz J.O. 2000. A refinement and validation of the MARKOR scale. Journal of the Academy of Marketing Science 28 (4): 527-539.

Narver J.C., Slater S.F. 1990. The effect of a market orientation on business profitability. Journal of Marketing 54 (4): 20-35.

Narver J.C., Slater S.F., MacLachlan D. L. 2004. Responsive and proactive market orientation and new-product success. Journal of Product Innovation Management 21 (5): 334-347.

O'Cass A., Ngo L. V., Siahtiri V. 2012. Examining the marketing planning-marketing capability interface and customer-centric performance in SMEs. Journal of Strategic Marketing 20 (6): 463-481.

O'Dwyer M., Gilmore A. 2018. Value and alliance capability and the formation of strategic alliances in SMEs: The impact of customer orientation and resource optimization. Journal of Business Research 87: 58-68.

Ozer A., Koçak A., Çelik O. 2006. Determinants of market orientation in accounting firms. Marketing Intelligence \& Planning 24 (6): 591-607.

Park C., Jun J., Lee T., Lee H. 2018. Customer orientation or employee orientation: Which matters more? The moderating role of firm size. Journal of Business \& Industrial Marketing 33 (7): 1001-1011.

Pekovic S., Rolland S., Gatignon H. 2016. Customer orientation and organizational innovation: The case of environmental management practices. Journal of Business \& Industrial Marketing 31 (7): 835-848.

Pelham A.M. 1997. Mediating influences on the relationship between market orienta- tion and profitability in small industrial firms. Journal of Marketing Theory and Practice 5 (3): 55-76.

Perry M.L., Shao A.T. 2005. Incumbents in a dynamic internet related services market: Does customer and competitive orientation hinder or help performance? Industrial Marketing Management 34 (6): 590-601.

Popov N. I., Tretyak O. A. 2014. Economic antecedents of low customer orientation of firms in BRIC countries. Russian Management Journal 12 (1): 109-138. (In Russian)

Roersen M.J., Kraaijenbrink J., Groen A.J. 2013. Marketing ignorance and the validity of Narver and Slater's MKTOR scale in high-tech Russian firms. Journal of Product Innovation Management 30 (3): 545-559.

Rozhkov A. 2014. Personal level customer orientation in Russian direct selling market. Trziste 26 (1): 7-22.

Rozhkov A.G., Rebiazina V.A., Smirnova M.M. 2014. The customer orientation of the company: The empirical test results in a case of the Russian market. Russian Management Journal 12 (3): 33-58. (In Russian)

Ruekert R.W. 1992. Developing a market orientation: An organizational strategy perspective. International Journal of Research in Marketing 9 (3): 225-245.

Sanzo M.J., Santos M.L., Vázquez R., Álvarez L. I. 2003. The role of market orientation in business dyadic relationships: Testing an integrator model. Journal of Marketing Management 19 (1-2): 73-107.

Sarkar S., Mishra P. 2017. Market orientation and customer-based corporate brand equity (CBCBE): A dyadic study of Indian B2B firms. Journal of Strategic Marketing 25 (5-6): 367-383.

Saxe R., Weitz B.A. 1982. The SOCO scale: A measure of the customer orientation of salespeople. Journal of Marketing Research 19 (3): 43-351.

Shapiro B.P. 1988. What the Hell is Market Oriented? (p.1-3). HBR Reprints.

Sheppard R. 2011. The evolution and conceptualization of market orientation: What managers ought to know. Journal of Management Policy and Practice 12 (6): 30. 
Siguaw J.A., Simpson P. M., Baker T.L. 1998. Effects of supplier market orientation on distributor market orientation and the channel relationship: The distributor perspective. Journal of Marketing 62 (3): 99 111.

Sin L. Y., Alan C. B., Heung V.C., Yim F.H. 2005. An analysis of the relationship between market orientation and business performance in the hotel industry. International Journal of Hospitality Management $\mathbf{2 4}$ (4): 555-577.

Singh R., Koshy A. 2011. Does salesperson's customer orientation create value in B2B relationships? Empirical evidence from India. Industrial Marketing Management $\mathbf{4 0}$ (1): 78-85.

Singh S., Ranchhod A. 2004. Market orientation and customer satisfaction: Evidence from British machine tool industry. Indus trial Marketing Management 33 (2): 135144.

Slater S.F., Narver J.C. 1994. Market orientation, customer value, and superior performance. Business Horizons 37 (2): 2229.

Smirnova M., Henneberg S.C., Ashnai B., Naudé P., Mouzas S. 2011. Understanding the role of marketing-purchasing collaboration in industrial markets: The case of Russia. Industrial Marketing Management 40 (1): 54-64.

Smirnova M. M., Rebiazina V.A., Frösén J. 2018. Customer orientation as a multidimensional construct: Evidence from the
Russian markets. Journal of Business Research 86: 457-467.

Snow C. C., Hrebiniak L. G. 1980. Strategy, distinctive competence, and organizational performance. Administrative Science Quarterly 25 (2): 317-336.

Tsiotsou R.H. 2010. Delineating the effect of market orientation on services performance: A component-wise approach. Service Industries Journal 30 (3): 375-403.

Viardot E. 2017. Branding in B2B: The value of consumer goods brands in industrial markets. Journal of Business \& Industrial Marketing 32 (3): 337-346.

Wang Q., Zhao X., Voss C. 2016. Customer orientation and innovation: A comparative study of manufacturing and service firms. International Journal of Production Economics 171: 221-230.

Wilden R., Gudergan S., Lings I. 2018. The interplay and growth implications of dynamic capabilities and market orientation. Industrial Marketing Management. [Electronic resource]. https://doi.org/10.1016/ j.indmarman.2018.11.001

Zhou K. Z., Brown J.R., Dev C.S. 2009. Market orientation, competitive advantage, and performance: A demand-based perspective. Journal of Business Research 62 (11): 1063-1070.

Ziggers G.W., Henseler J. 2016. The reinforcing effect of a firm's customer orientation and supply-base orientation on performance. Industrial Marketing Management 52: $18-26$.

Initial Submission: February 18, 2019 Final Version Accepted: March 22, 2019

\section{Клиентоориентированность В2В-колпаний на развивающихся рынках: результаты исследования российского рынка}

\section{О. В. Гулакова, В.А.Ребязина}

Факультет бизнеса и менеджмента Национального исследовательского университета «Высшая школа экономики», Россия

\section{М.М.Слирнова}

Институт «Высшая школа менеджмента» Санкт-Петербургского государственного университета, Россия 
Несмотря на то что клиентоориентированность (КО) начала широко изучаться с 1990-х гг., попыток пересмотреть эту концепцию с учетом специфики промышленных рынков, в частности в контексте развивающейся экономики, практически не предпринималось. В данной статье рассматриваются особенности КО В2В-компаний на примере развивающейся экономики России. Эмпирическое исследование среди 272 российских В2В-компаний показало, что распространенные инструменты оценки КО могут быть использованы в качестве интегрированной шкалы. Результаты анализа выявили очень важный аспект КО, помогающий различить клиентоориентированные компании и компании с лишь «декларируемой» КО. Исследование показывает необходимость критической оценки устоявшихся маркетинговых концепций и подходов к их измерению на В2В-рынках в развивающихся экономиках.

Ключевые слова: ориентация на клиента, промышленные рынки, Россия.

JEL: M31.

For citation: Gulakova O.V., Rebiazina V.A., Smirnova M. M. Customer orientation of B2B firms in emerging markets: Evidence from Russia. Russian Management Journal 17 (1): 71-96.

Статья поступила в редакцию 18 февраля 2019 г. Принятак публикации 22 марта 2019 г. 